\title{
ВПЛИВ СТРУМУ ВИСОКОЇ ЧАСТОТИ LIGA SURE НА СТРУКТУРУ ЩИТОПОДІБНОЇ ЗАЛОЗИ ПРИ ВУЗЛОВОМУ ЗОБІ
}

ДВНЗ « Тернопільський державний медичний університет імені І.Я. Горбачевського»

\begin{abstract}
Резюме. У хірургічному лікуванні патології щитоподібної залози все частіше використовуються фізичні методи дисекції і коагуляції тканин із застосуванням монополярної і біполярної коагуляції, а також електрогенератора високої частоти Liga Sure. Нез'ясованим є морфофункціональний стан залишеної частки щитоподібної залози при виконанні гемітиреоїдектомії з допомогою даних технологій. Нами використано операційно видалені частки щитоподібної залози із застосуванням технологіï Liga Sure 12 хворих на вузловий зоб для
\end{abstract}

Вступ. Незважаючи на інтенсивне впровадження нових сучасних технологій, які покращують діагностичні можливості патології щитоподібної залози, за останні роки спостерігається збільшення серед них відсотка захворюваності на вузловий зоб [1, 3]. Основним методом лікування пацієнтів протягом тривалого часу залишається хірургічний. Але частота ускладнень після оперативних втручань залишається досить високою, у межах 2,5-5,0 \%. Широке впровадження нових прогресивних малоінвазивних технологій, перш за все удосконалення методів гемостазу, дозволило значно знизити їх кількість [6-9]. У наш час операціями вибору вважаються фізичні методи дисекції і коагуляції тканин із застосуванням монополярної і біполярної коагуляції, а також електрогенератора високої частоти Liga Sure $[4,5,11]$. Але і зазначені методи мають низку недоліків, особливо це стосується впливу на навколовузлові тканини струму високої частоти. Залишається нез'ясованим морфофункціональний стан залишеної частки щитоподібної залози при застосуванні органоощадної операції, від чого залежить у подальшому її регенераторна здатність. Зазначений нез'ясований морфологічний аспект проблеми впливу високочастотного струму на структуру залози стало основою для вибору даного дослідження.

Мета дослідження. 3'ясувати морфологічні зміни тканини щитоподібної залози при вузловому зобі за умов дії генератора струму високої частоти Liga Sure.

Матеріал і методи. Для морфологічного дослідження використано операційно видалені частки щитоподібної залози із застосуванням технології Liga Sure 12 хворих на вузловий зоб. Середній вік пацієнтів становив 45 років. Тканину залози фіксували в $10 \%$ розчині нейтрального формаліну і вивчали як макро-, так і мікроскопічно згідно з Угодою про науково-практичне співробітництво ВДНЗ «Тернопільський державний медичний університет імені І.Я.Горбачевського» MO3 України та Тернопільського обласного патолого-анатомічного бюро. Зразки тканини зне- морфологічного дослідження. Методами гістологічного i морфометричного дослідження щитоподібної залози встановлено, що ії ремоделювання залежать від відстані безпосередньої дії високочастотного струму: у місці накладання бранші - коагуляційний некроз, у перифокальній ділянці - морфофункціональні прояви стресової реакції і у віддаленій - структура вузлового зоба незмінена.

Ключові слова: вузловий зоб, високочастотний струм, Liga Sure, морфологія, морфометрія.

воднювали в спиртах і ущільнювали парафіном. Депарафінізовані зрізи забарвлювали гематоксиліном і еозином, фукселіном Харта та трихромом за методом Малорі. Морфометрію відносного об'єму тиреоцитів, фолікулів із базофільним колоїдом і фолікулів із слабко еозинофільним колоїдом та строми проводили із застосуванням сітки Г.Г.Автанділова (2002) у двох ділянках видаленої частки залози, а саме перифокально електрокоагуляції і навколовузловій ділянках. Гістологічні зрізи досліджували за допомогою мікроскопів SEOSCAN та Люмам Р-8 при різних збільшеннях. Для фотодокументації і морфометрії зображення із мікроскопів виводили на монітор комп’ютера за допомогою відеокамери VISION Color CCD Camera і програми InterVideoWinDVR.

Результати дослідження та їх обговорення. При гістологічному дослідженні в ділянці дії високочастотного струму Liga Sure виявлено безструктурну тканину, яка добре забарвлюється еозином. Контури фолікулів не верифікуються. Місцями наявне просякання тканини гемолізованими еритроцитами.

У перифокальних ділянках, відносно коагуляційного некрозу, що захоплювали до 2-3 мм, виявлялися морфологічні прояви ремоделювання щитоподібної залози, які проявлялися в морфологічному ремоделюванні тиреоцитів у поєднанні 3 різко вираженою реакцією мікроциркуляторного русла. Спостерігалося злиття апікальної мембрани тиреоцитів із резорбційними вакуолями, а також десквамація їх у просвіт фолікула та втрата частиною фолікулів колоїду (рис. 2). Зазначені прояви морфологічних змін, за умов впливу високочастотного струму, доцільно вважати проявом „аварійної” реакції секреторної функції щитоподібної залози на дію високочастотного струму. Дія струму стверджується такими ознаками, як зміна форми ядер міоцитів судин і стромальних клітин. Вони приймають видовжену форму та інтенсивно забарвлюються гемотоксиліном, що $є$ морфологічною ознакою відповіді клітин на зазначений патогенний чинник. 


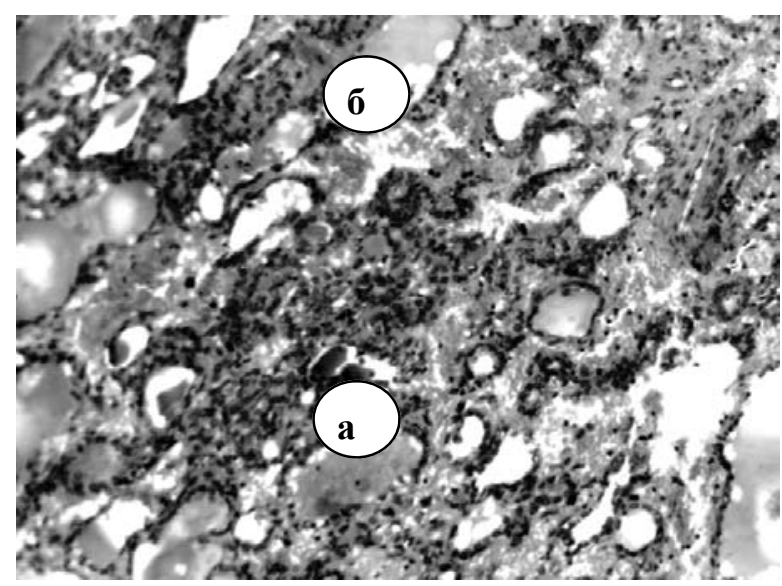

Рис. 1. Діапедезні крововиливи (a), резорбція колоїду (б). Гістологічний зріз щитоподібної залози біля коагуляційного некрозу, спричиненого дією струму. Заб. гематоксиліном і еозином. Об. $10^{\mathrm{x}}$, Ок. $10^{\mathrm{x}}$

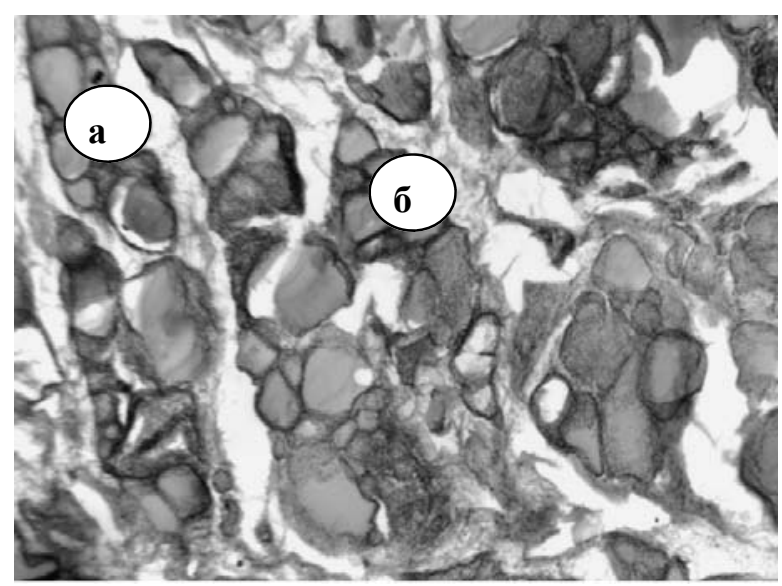

Рис. 3. Гетерогенність величини фолікулів (а). Сполучнотканинні прошарки (б). Гістологічний зріз у периферійній ділянці. Заб.- гематоксиліном і еозином. Об. $10^{\mathrm{x}}$.Ок. $12^{\mathrm{x}}$

Порушення мікроциркуляції були неспецифічними і проявлялися різним ступенем виразності морфологічних змін, а саме стромальним набряком, гострим повнокров'ям капілярів, діапедезними крововиливами та колоїдорагіями. У більшості сегментарних артерій субендотеліальний прошарок потовщений із причини плазматичного просякання та еритродіапедезу. Внутрішня еластична мембрана 3 проявами розщеплення та фрагментації. У просвіті судин виявляються тро-

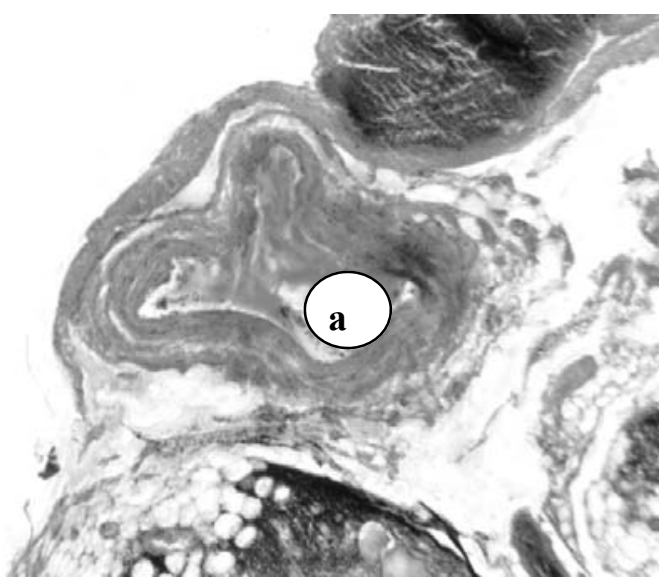

Рис. 2. Тромбоз із утворенням «колагенової пломби» у просвіті судини (а). Гістологічний зріз щитоподібної залози у ділянці дії високочастотного струму. Заб. гематоксиліном і еозином. Об. $10^{\mathrm{x}}$.Ок $10^{\mathrm{x}}$

мби з гомогенної еозинофільної маси з домішками лізованих еритроцитів, що трактується як утворення «колагенової пломби» (рис. 2).

Цей феномен Никитенко А. И. із співавт. (2005) пояснює тим, що висока сила струму при застосуванні Liga Sure проходить через тканину дуже швидко, що разом 3 імпульсною подачею енергії сприяє рівномірному плавленню тканин i утворенню пломби в просвіті судини.

У навколовузловій зоні структурні зміни залози відповідали морфології макро-мікро фолікулярного колоїдного зоба. Гістологічно на більшості полів зору паренхіма щитоподібної залози гетерогенна. Поряд із великими фолікулами, заповненими щільним колоїдом, наявні менші за розмірами фолікули. На перший план виходять дистрофічні та склеротичні зміни, а також лімфоїдна інфільтрація строми. Сполучнотканинні прошарки проникали між групами фолікулів, утворюючи псевдовузли. Колоїд у великих фолікулах оксифільний, а у фолікулах малих розмірів - базофільний. Резорбційні вакуолі були поодинокі.

При дослідженні внутрішньоорганних судин відмічено потовщення їх стінки за рахунок набряку субінтимального прошарку, розщеплення та фрагментацію еластичних волокон. Ендотеліоцити збільшені в об'ємі, видовженої форми, добре сприймають гематоксилін, місцями злущені.

Таблиця

Відносні параметри (\%) структур щитоподібної залози залежно від відстані до коагуляційного некрозу, спричиненого високочастотним струмом $(\mathrm{M} \pm \mathrm{m})$

\begin{tabular}{|c|c|c|c|c|}
\hline \multirow[b]{2}{*}{ Ділянки дослідження } & \multicolumn{4}{|c|}{ Параметри (відносний об’єм, \%) } \\
\hline & $\begin{array}{l}\text { Тиреоцити } \\
\text { (\%) }\end{array}$ & $\begin{array}{c}\text { Фолікули із базофілією } \\
\text { колоїду (\%) }\end{array}$ & $\begin{array}{c}\text { Фолікули із ослабле- } \\
\text { ною еозинофілією } \\
\text { колоїду (\%) }\end{array}$ & Строма (\%) \\
\hline $\begin{array}{c}\text { Біля коагуляційного } \\
\text { некрозу }\end{array}$ & $14,62 \pm 0,28$ & $16,98 \pm 0,20$ & $18,73 \pm 0,13$ & $49,67 \pm 0,26$ \\
\hline Навколовузлова & $\begin{array}{l}11,84 \pm 0,14 \\
* p<0,001\end{array}$ & $\begin{array}{l}22,97 \pm 0,22 \\
* \mathrm{p}<0,001\end{array}$ & $\begin{array}{c}24,06 \pm 0,19 \\
* \mathrm{p}<0,001\end{array}$ & $\begin{array}{l}41,13 \pm 0,15 \\
* p<0,001\end{array}$ \\
\hline
\end{tabular}

Примітка. * - вірогідність різниці порівняно з даними перифокальної по відношенню до некрозу ділянки 
Дані гістологічного дослідження свідчать, що прояви ремоделювання тканини щитоподібної залози залежать від відстані безпосередньої дії високочастотного струму. Це підтверджується також і морфометричними даними (табл.).

Так, у навколовузловій ділянці, порівняно 3 ділянкою біля коагуляційного некрозу, спостерігається зменшення відносного об'єму тиреоцитів і строми в поєднанні зі збільшенням відносного об’єму колоїду. Таким чином, можна припустити, що тканина залишеної частки щитоподібної залози після проведення органоощадної операції методом Liga Sure має всі резерви для компенсаторної тканинної гіперплазії.

\section{Висновки}

1. У ділянці безпосередньої дії високочастотного струму генерованого Liga Sure тканина щитоподібної залози при вузловому зобі піддається коагуляційному некрозу.

2. У перифокальній ділянці навколо коагуляціонного некрозу тканина щитоподібної залози зазнає ремоделюванння за типом аварійної реакції на термічний стрес у поєднанні з утворенням «коагуляційної пломби» в магістральних судинах.

3. У віддалених від безпосередньої дії струму навколовузлових ділянках зберігається структура макро-мікрофолікулярного колоїдного зоба, що можна розцінювати як резерв для подальшої компенсаторної тканинної гіперплазії в післяопераційному періоді.

Перспектива подальших досліджень. Обсяг проведених досліджень є невеликим, для більш об'єктивного аналізу ефективності застосування Liga Sure в хірургії щитоподібної залози доцільно провести аналіз на більш репрезентабельному матеріалі.

\section{Література}

1. Валдина Е.А. Амбулаторный этап в диагностике и лечении дифференцированного рака щитовидной железы / Е.А. Валдина // Стационарозамещающие технологии. Амбулаторная хирургия. - 2007. - № 4 (28). - C. 31-32.

2. Васьков В.М. Нерешенные вопросы хирургического лечения заболеваний щитовидной железы / В.М. Васьков, Т.А. Масальская // Актуал. пробл. заболеваний щитовидной железы. Тезисы 1 Всероссийской конференции. - М., 2000. - С. 35.

3. Коваленко Ю.В. Послеоперационный рецедивный узловой (многоузловой) нетоксичный зоб / Ю.В. Коваленко // Саратов. науч.-мед. ж. - 2011. - Т. 7, № 4. C. $975-980$.

4. Применение генератора Liga Sure и технологии «плавающего разреза» в хирургии щитовидной железы / А. И. Никитенко., А. Н. Катков, А. М Желаннов [и др.] // Нижегород. мед. ж. - 2005. - № 2. - С. 112-117.

5. Никитенко А.И. Применение генератора Liga Sure в хирургии щитовидной железы / А.И. Никитенко, А.Н. Катков, В.А. Овчинников // Сб. тез. Всероссийского конгресса хирургов. - М., 2005. - С. 47.

6. Цуканов Ю.Т. Варианты и результаты эндоскопической хирургии щитовидной железы / Ю.Т. Цуканов, А.Ю. Цуканов // Ендоскоп. хірургія. - 2006. - № 2. C. 149.

7. Хатьков И.Е. Топографо-анатомическое обоснование эндовидеохирургических оперативных вмешательств на щитовидной железе из отдаленных доступов / И.Е. Хатьков, А.Н. Орлова // Эндоскоп. хирургия. 2009. - № 5. - C. 39-40.

8. Barczinski M. Two years of minimally invasive videoassisted thyroidectomy in goiter region / M. Barczinski // 10-th World Congress of EndoscopicSurgery. - Berlin, 2006. - P. 39.

9. Videoassisted thyroidectomy: indications and results / P. Miccoli, P. Berti, G.L. Frustaci [et al.]// Langenbecks Arch. Surg. - 2006 Apr. - Vol. 391(2). - P. 68-71.

10. Total video-endoscopic thyroid resection via axillobilateral- breast-approach (ABBA) // 10-th World Congress of Endoscopic Surgery. - Berlin, 2006. - № 39. - P. 40-41.

11. Witzel K. The transoral access in endoscopic thyroid resection / K. Witzel // 15-th International Congress of the European Association for Endoscopic Surgery (EAESS). - Athens, 2007. - P. 24.

\section{ВЛИЯНИЕ ТОКА ВЫСОКОЙ ЧАСТОТЫ LIGA SURE НА СТРОЕНИЕ ЩИТОВИДНОЙ ЖЕЛЕЗЫ ПРИ УЗЛОВОМ ЗОБЕ}

\section{T.В. Ермакова}

Резюме. В хирургическом лечении патологии щитовидной железы все чаще используются методы диссекции и коагуляции тканей с применением монополярной и биполярной коагуляции, а также электрогенератора высокой частоты Liga Sure. Невыясненным является морфофункциональное состояние оставленной доли щитовидной железы при выполнении гемитиреоидектомии с помощью данных технологий. Нами использованы операционно удалены доли щитовидной железы с применением технологии Liga Sure 12 больных узловым зобом для морфологического исследования. Методами гистологического и морфометрического исследования щитовидной железы установлено, что ее ремоделирования зависят от расстояния непосредственного воздействия высокочастотного тока: в месте наложения бранши - коагуляционный некроз, в перифокальной области - морфофункциональные проявления стрессовой реакции и в отдаленной - структура узлового зоба изменена.

Ключевые слова: узловой зоб, высокочастотный ток, Liga Sure, морфология, морфометрия.

\section{INFLUENCE OF HIGH FREQUENCY CURRENT LIGA SURE ON THE STRUCTURE OF THYROID GLAND IN NODULAR GOITER}

\section{T.V. Yermakova}

Abstract. In the surgical treatment of thyroid disease physical methods of dissection and coagulation of tissue using monopolar and bipolar coagulation and high frequency electric Liga Sure have been increasingly used. Morphofunctional state of the abandoned lobe of the thyroid gland in the performance of hemithyroidectomy using these technologies is still 
unclear. We removed surgically thyroid particles using technology Liga Sure 12 in patients with nodular goiter for morphological studies. By means of methods of histological and morphometric study of the thyroid gland we revealed that its remodeling depends on the distance from the direct action of high-frequency current, in place of imposition Branche - coagulation necrosis in the perifocal area - morphological manifestations of stress response and in the long - nodular goiter the structure is unchanged.

Key words: nodular goiter, radio-frequency current, Liga Sure, morphology, morphometry.

I.Ya. Horbachevsky State Medical University (Ternopil)

Рецензент - проф. І.С. Давиденко

Buk. Med. Herald. - 2015. - Vol. 19, № 4 (76). - P. 71-74

Надійшла до редакції 01.04.2015 року

(C) Т.В. Єрмакова, 2015 